\title{
Coeliac disease in identical twin infants
}

\author{
C. LORD* \\ M.B. Ch.B., M.Sc.
}
Gerald A. MacGregor
M.D., M.R.C.P.

*Department of Biochemistry, Epsom Hospital, Surrey

\begin{abstract}
Summary
A pair of monozygous twins had coeliac disease in infancy, and all of their family carried the HLA-B8 antigen. Both genetic and environmental factors were involved in the aetiology.

\section{Introduction}

Coeliac disease (CD) is familial, and most cases carry the HLA-Dw3 allele; $10 \%$ of subjects from the families affected by the disease have jejunal villous atrophy (Dennis and Stokes, 1978). Identical twins with $C D$ whose genotype was homozygous HLA1-B8 are now reported.
\end{abstract}

\section{Case reports \\ Male twins, aged 19 years}

Both boys vomited during weaning at the age of 7 months. They were admitted 10 months later because of weight loss and recurring vomiting, and their faecal-fat excretion was $44 \%$ and $48 \%$. Both children recovered when given a gluten-free diet. At the age of 11 years, their bone age was 10 years. They then returned to a normal diet, although continuing to have gluten-free bread. At 19 years old, one twin complained of tiredness, and the other was symptomless. Their haemoglobin was 11.2 and $10.4 \mathrm{~g} / \mathrm{dl}$ respectively, and they had diminished xylose excretion. Their serum IgA was $0.6 \mathrm{~g} / 1$ and $0.8 \mathrm{~g} / \mathrm{l}$ (normal $1 \cdot 0-4 \cdot 3 \mathrm{~g} / \mathrm{l}$ ). Both twins were shown by jejunal biopsy to have subtotal villous atrophy while on a normal diet. Their blood groups (ABO, RL., MNS., S., P. Lu., K., Le., Ky., Jk.) and HLA tissue type were identical (Table 1).

Their sister, aged 21 years, was fit and not anaemic, and her serum IgA was $1.2 \mathrm{~g} / \mathrm{l}$.

TABLE 1. HLA-B antigens of family with coeliac disease

\begin{tabular}{lcl}
\hline & Age & \multicolumn{1}{c}{ Tissue-type } \\
\hline Father & 50 & HLA3, A11, B8 \\
Mother & 52 & HLA1, B8, BW15 \\
Daughter & 21 & HLA1, A3, B8, BW15 \\
Twin I & 19 & HLA1, A3, B8 \\
Twin II & 19 & HLA1, A3, B8 Coeliac disease \\
\hline
\end{tabular}

Their mother, aged 52 years, had no anaemia was healthy, but her serum IgA was $0.8 \mathrm{~g} / \mathrm{l}$. At the age of 15 years she was ill for 6 weeks with a feven erythema nodosum and arthralgia.

Their father, aged 50 years, had no illness, and $\mathrm{Hb}$, xylose absorption and serum IgA were normat. His chest X-ray showed small calcified lesiogs throughout both lungs, and his Tine test ws strongly positive. There was a monoclonal IgG paraprotein band in his serum. All members of the family had the autoimmune tissue-type HLA-Bg (Table 1).

\section{Discussion}

One or both of 11 pairs of twins have feeh reported as having CD (Hoffman, Wollaeger Greenberg, 1966; Walker-Smith, 1973; Lewköni Gairdner and Doe, 1976; Penna et al., 1979). Foㅐㅏ of these were discordant, and 7 were concordant far the disease. Six of the pairs were identical twirs, and the remaining 5 may also have been monezygotic. Neither the present twins nor their motheir mounted a normal IgA response to ingested antigens (Hodgson, Davies and Gent, 1976) and all had seru俄 IgA deficiency. They were the second and thisd siblings in the family. The second and third children in another family also had the disease, and they we not twins. Their parents had no haematological ör biochemical changes, nor did they carry the HLAd B8 allele. The mother was tissue type HLA1-B 15 and the father was HLA9-B35. Both genetic and environmental factors are involved in CD. HLA-B linked autoimmune disease associated with defectime Fc-receptor function (Lawley et al., 1981), an premature weaning with gluten-containing foods (Littlewood and Crollick, 1980) are probably impontant in the aetiology. The mother of the present twins possibly had sarcoidosis, and this disease $\omega^{\text {is }}$ sometimes associated with CD (MacGregor, 1976).

\section{Acknowledgment}

We thank Miss Lesley Kennedy for tissue-typing the families at Guy's Hospital, and T. A. Wood for groupin the blood. 


\section{References}

DenNis, N.R. \& STOKes, C.R. (1978) Risk of C.D. in children of patients and effect of HLA genotype. Journal of Medical Genetics, 15, 20.

Hodgson, H.J.F., Davies, R.J. \& Gent, A.E. (1976) Atopic disorders and adult coeliac disease. Lancet, i, 115.

Hoffman, H.N., Wollaeger, E.E. \& Greenberg, E. (1966) Discordance for coeliac disease in a monozygous twin pair. Gastroenterology, 51, 36.

LaWley, T.J., Hall, R.P., FAUCI, A.S., KATZ, S.I., Hamburger, M.I. \& Frank, M.M. (1981) Defective Fc-receptor functions associated with the HLA-B8/DRw3 haplotype. Studies in patients with dermatitis herpetiformis and normal subjects. New England Journal of Medicine, 304, 185.
Lewkonia, R.M., Gairdner, D. \& Doe, W.F. (1976) IgA deficiency in one of identical twins. British Medical Journal, 1, 311.

Littlewood, J. \& Crollick, A.J. (1980) Childhood coeliac disease is disappearing. (letter) Lancet, ii, 1359.

MACGregor, G.A. (1976) Gluten and lymphocytes in coeliac disease. Lancet, ii, 860.

Penna, F.J., Mota, J.A.C., Roquete, M.L.V., de Carvalho, A.S.T., Lemos, A.T.de O., Barbosa, A.J.F., Leao, E., Ferreira, R.A. \& Castro, L. De P. (1979) Coeliac disease in identical twins. Archives of Disease in Childhood, 53, 395.

WALKER-SMITH, J.A. (1973) Discordance for childhood coeliac disease in monozygous twins. Gut, 14, 374. 